This is the final peer-reviewed accepted manuscript of: Kwadjo, KE et al. Identification of Nedotepa curta Dmitriev as a potential vector of the Cote d'Ivoire lethal yellowing phytoplasma in coconut palms sole or in mixed infection with a 'Candidates Phytoplasma asteris'-related strain, which has been published in final form in CROP PROTECTION Volume: 110 Pages: 48-56. The final published version is available online at: https://doi.org/10.1016/j.cropro.2017.12.015.

(C) 2017 Elsevier. This manuscript version is made available under the Creative Commons AttributionNonCommercial-NoDerivs (CC BY-NC-ND) 4.0 International License

(http://creativecommons.org/licenses/by-nc-nd/4.0/)

\title{
Identification of Nedotepa curta Dmitriev as a potential vector of the Côte d'Ivoire lethal yellowing phytoplasma in coconut palms sole or in mixed infection with a 'Candidatus Phytoplasma asteris'-related strain
}

\author{
Koffi Eric Kwadjo ${ }^{a}$, N.'Djiha Isabelle Beugréb ${ }^{\text {, Christopher H. Dietrich }}{ }^{c}$, \\ Adaba Tano Thierry Kodjo ${ }^{a}$, Hortense Atta Diallo ${ }^{a}$, Ndede Yankey ${ }^{\mathrm{d}}$, Sylvester Dery ${ }^{\mathrm{d}}$, \\ Michael Wilson $^{\mathrm{e}}$, Jean Louis Konan Konan ${ }^{\mathrm{b}}$, Nicoletta Contaldo ${ }^{\mathrm{f}}$, Samanta Paltrinieri ${ }^{\mathrm{f}}$, \\ Assunta Bertaccini ${ }^{\mathrm{f}}$, Yaima Arocha Rosete ${ }^{\text {g,* }}$ \\ a Université Nangui Abrogoua, 02 BP 801 Abidjan 02, Cote d'Ivoire \\ ' Station de Recherche "Marc Delorme", Centre National de Recherche Agronomique (CNRA), 07 BP 13 Abidjan, Cote d'Ivoire \\ ' Illinois Natural History Survey, University of Illinois, 1816 S Oak St., Champaign, IL 61820, USA \\ d Council for Scientific Research Program-Oil Palm Research Institute-Coconut Research Program (CSIR-OPRI), Off Well Road Box 254, Sekondi, Western Region, Ghana \\ e Department of Biodiversity and Systematic Biology, Museum of Wales, Cardiff CF10 3NP, United Kingdom \\ ${ }^{\mathbf{f}}$ Department of Agricultural Sciences, Alma Mater Studiorum - University of Bologna, viale Fanin 42, 40127 Bologna, Italy \\ ${ }^{\mathrm{g}}$ Sporometrics, 219 Dufferin Street, Suite 20C, Toronto, ON M6K 3J1, Canada
}

\section{A R T I C L E I N F O}

\section{Keywords:}

Coconut lethal yellowing

Phytoplasma

Potential vector

16SrXXII

Côte d'Ivoire

Nedotepa curta

\begin{abstract}
A B S T R A C T
Over 360 Hemiptera specimens were collected using sweep nets and hand-made aspirators from coconut palm fronds in six villages of Grand-Lahou. Eight families were identified including Aphrophoridae, Achilidae, Derbidae, Flatidae, Membracidae, Pentatomidae, Tropiduchidae, and Cicadellidae, the latter being the most abundant throughout the surveyed villages. PCR assays with primers targeting the 16S rRNA and the secA translocation protein genes yielded PCR amplicons from 216 out of 296 (73\%) of the tested specimens of a newly identified cicadellid leafhopper, Nedotepa curta Dmitriev. PCR amplicons were purified, cloned and sequenced. The 16S rDNA and secA sequences from $N$. curta showed a 99\% of sequence identity with those of the Côte d'Ivoire lethal yellowing (CILY) phytoplasma, member of subgroup 16SrXXII-B 'Candidatus Phytoplasma palmicola'-related strain, previously identified in coconut-growing villages of Grand-Lahou. This suggested $N$. curta as a potential vector for the CILY phytoplasma. Four symptomatic coconut palms (7.4\%) were found infected by a phytoplasma of group 16SrI, in mixed infection with the CILY phytoplasma (16SrXXII-B) in two palms, and alone in the other two palms, where the CILY phytoplasma was not detected. The 16SrI phytoplasma was also found in two $N$. curta specimens, and in the weeds Dalbergia saxatilis and Baphia nitida. Results indicating that mixed infection of both 16SrXXII-B and 16SrI phytoplasmas occurs in coconut palms affected by CILY in GrandLahou, and may impact disease management and control.
\end{abstract}

\section{Introduction}

Côte d'Ivoire lethal yellowing (CILY) of coconut palm was first reported in 2013 in Grand-Lahou, and since then it has rapidly spread to several coconut-growing villages where over 400 ha have been destroyed and another 7000 ha are under threat (Arocha-Rosete et al., 2014). Lethal yellowing (LY)-like diseases of palms have been associated with a number of phytoplasmas (Sullivan and Harrison, 2013) worldwide that have killed millions of palms in the last 40 years.

Phytoplasmas are bacteria of the class Mollicutes transmitted by phloem-feeding insect species within the order Hemiptera, particularly Cicadellidae (leafhoppers), but also Cercopidae, Cixiidae, Derbidae, Delphacidae, and Psyllidae (Weintraub and Beanland, 2006). Phytoplasmas are transmitted by a narrow range of hemipteran species, whereas their plant host range is usually broader (Foissac and Wilson, 2010). Only about $1 \%$ of known leafhopper species have been shown to be capable of transmitting plant pathogens (Dietrich, 2013), so the number of actual or potential vectors is likely to be much larger than the approximately 200 vector species currently documented.

Despite the widespread occurrence of phytoplasmas in coconuts in

\footnotetext{
* Corresponding author

E-mail address: yarosete@sporometrics.com (Y. Arocha Roset)
} 
Africa, Asia and the Caribbean, many of the insect vectors of LY-like coconut diseases have not been identified. So far, the cixiid Haplaxius crudus (Van Duzee) has been the only species reported as vector for the LY phytoplasma in Florida (Howard, 2001), while the insect vector for the long known Cape St Paul Wilt Disease (CSPWD) of coconuts in Ghana remains elusive. Although two species, Diostrombus sp. (Derbidae) and Haplaxius adiopodoumeensis (Synave) (Cixiidae), formerly placed in the genus Myndus (Myndus adiopodoumeensis) (Ceotto and Bourgoin, 2008) were found to carry the CSPWD phytoplasma, transmission trials were inconclusive (Philippe et al., 2009). An undescribed species of Cedusa (Derbidae) has been implicated in the transmission of palm phytoplasmas in Jamaica (Brown et al., 2006), but no transmission test was done. In the Cabo Delgado province of Mozambique, some pentatomids of the species Platacantha lutea (Westwood) were found to carry the same phytoplasmas as those identified in the diseased coconut on which they were found (Dollet et al., 2011). In Tanzania, Diostrombus mkurangai Wilson (Derbidae) and a few specimens of Meenoplus spp. (Meenoplidae) were PCR positive for phytoplasmas but experimental transmission was never carried out (Mpunami et al., 2000).

Interestingly, D. mkurangai was identified as a potential vector of LY in Mozambique (Bila, 2016), where it may also carry the Tanzanian LD phytoplasma type; likewise $D$. mkurangai in Tanzania may possibly harbor 'Candidatus Phytoplasma palmicola' or related strains. Patara albida (Derbidae) was identified as a potential vector for the Texas Decline palm phytoplasma (Brown et al., 2006), and a new species within the derbid genus Omolicna was also described as carrier of the same phytoplasma (Halbert et al., 2014). Two other derbids, D. mkurangai, and Proutista moesta (Westwood) transmit other palm pathogens in Africa (Howard, 2001) and Kerala Wilt disease of coconut in India (Edwin and Mohankumar, 2007). More recently, a potential vector for the Bogia Coconut Syndrome phytoplasma was identified in Papua New Guinea (Lu et al., 2016).

LY and LD phytoplasmas affecting coconut and other palm species exhibit genetic variation among strains within and from North/Central America and the Caribbean, and Africa (Sullivan and Harrison, 2013). The group 16SrIV appears to be limited to the Americas, the Caribbean, and Tanzania (Danyo 2011), and is divided into several subgroups that include the 16SrIV-A (Palm LY, Florida), 16SrIV-B (Yucatan LD, Mexico), 16SrIV-C (Tanzania and Kenya LD), 16SrIV-D (Texas Phoenix Decline, TPD, and Mexico Carludovica palmata yellows, CPY) (Harrison et al., 2002), and 16SrIV-F (Washingtonia robusta, Florida) (Harrison et al., 2008).

The CILY phytoplasma was recently classified as a member of group 16SrXXII, subgroup -B, 'Ca. P. palmicola' - related strain (Harrison et al., 2014) that comprises the CSPWD phytoplasma from Ghana, which has destroyed the Ghanaian coconut industry in the last 20 years (Danyo, 2011). Also within the 16SrXXII group, the subgroup 16SrXXII-A was officially named as the new taxon identified in Mozambique ' $\mathrm{Ca}$. P. palmicola' that also includes the lethal decline (LD) strain from Nigeria (Harrison et al., 2014). Bila et al. (2015) identified three phytoplasma strains associated with the LY in Mozambique, which included the ' $\mathrm{Ca}$. P. palmicola' (16SrXXII-A), the Tanzanian LD strain (16SrIV-C), and a 'Ca. P. pini' - related strain (16SrXXI-A); this latter was found in co-infection with a 'Ca. P. palmicola' strain.

This paper reports the results of surveys conducted in Grand-Lahou aiming at characterizing the Hemiptera entomofauna of the coconut farms affected by CILY in order to identify the potential insect vector(s) for the CILY phytoplasma. Total DNA samples from coconut palms previously extracted from samples collected during surveys in CILYaffected villages in Grand-Lahou, and weeds present in the coconut farms were PCR- and sequence-assessed with universal primers targeting ribosomal (16S rRNA) and non-ribosomal ( $\sec \mathrm{A})$ genes. To facilitate identification of the potential vector, a description of the main morphological traits of the typhlocybinae, Nedotepa curta Dmitriev, in Grand-Lahou, Côte d'Ivoire, including comparisons to related African leafhopper species not specified in the original description of the species, is also provided.

\section{Materials and methods}

2.1. Plant and entomofauna sampling in coconut groves affected by CILY in Grand-Lahou

Over 360 specimens of Hemiptera were collected with a sweep net and hand-made aspirator from the undersides of coconut leaves exhibiting CILY symptoms from stages 1, 2 and 3 during surveys conducted in six villages of Grand-Lahou from March 2015 to September 2016. Specimens collected in the field were placed by genus in $1.5 \mathrm{~mL}$ microtubes corresponding to each coconut palm and representing each disease stage surveyed per village. As previously described (Arocha Rosete et al., 2017), symptoms of disease stage 1 correspond with palms showing the starting of yellowing from the older leaves as well as the starting of the blackening of the inflorescences and premature nut drop, while the disease stage 2 of CILY is characterized by the yellowing of the older leaves progressing to the younger leaves, and an advanced progress of the inflorescence blackening. For the disease stage 3 , the yellowed leaves eventually turn brown, desiccate, and hang down forming a skirt around the trunk before falling and become a 'telephone', the typical sign of disease stage 4 or terminal stage. Trunk borings from three coconut palms representing each disease stage in each village, and one symptomless palm per village were obtained as previously described (Arocha Rosete et al., 2017). Hemiptera specimens were also collected from two weed species Dalbergia saxatilis Hook. f. (Leguminosae - Papilionoideae), and Baphia nitida Lodd. (Fabaceae) from the village of Badadon. Leaf samples of the weed species were also collected.

Specimens were transported in coolers with ice packs to the Entomology Laboratory of the Once in the lab, each microtube was sorted to genus/species level, and a total of 10 female and 10 male specimen representatives of Nedotepa curta were selected, and sent out for morphology-based confirmation of the taxonomic identification (genus and species) to Dr. Michael Wilson, Museum of Wales, United Kingdom; and Dr. Christopher Dietrich, University of Illinois, USA. Voucher specimens of identified insects are deposited in the National Museum of Wales and the Illinois Natural History Survey, Champaign. N. curta specimens collected in Ghana and confirmed as phytoplasma-free were also sent to USA and UK and used for morphological comparisons to confirm that the populations from Côte d'Ivoire and Ghana are conspecific.

\subsection{Nested polymerase chain reaction (nPCR)}

Total DNA extraction was performed with the FastDNA Spin Kit (MP Biomedicals, USA). For plants, $100 \mathrm{mg}$ of midribs finely cut with sterile scalpels were used. For hemipteran, batches of 5 individuals corresponding to each genus and species previously sorted were placed in $1.5 \mathrm{~mL}$ microtubes and processed. Phytoplasma-free $N$. curta specimens received from Ghana were also separated in $1.5 \mathrm{~mL}$ microtubes each containing 5 individuals, and used as negative controls for PCR. For all PCR reactions, $50 \mathrm{ng}$ of total DNA extracted was added to a $25 \mu \mathrm{L}$ PCR reaction (PCR ready-to-go-beads, GE Healthcare, United Kingdom) containing $0.4 \mu \mathrm{M}$ of each primer. Universal primers P1 (Deng and Hiruki, 1991) and P7 (Schneider et al., 1995) nested with primers G813F/AwkaSR (Tymon et al., 1998) were used to amplify the partial 16S rRNA, intergenic spacer and 23S gene of the CILY phytoplasma. One microliter of the 40-fold diluted P1/P7 PCR products was used in the PCR reaction. The R16F2n/R2 (Gundersen and Lee, 1996) and U5/ U3 (Lorenz et al., 1995) fragments were amplified through nested PCR using the primer pairs R16mF1/R1 (Gundersen and Lee, 1996) and P1/ $\mathrm{P7}$, respectively, for the direct PCR reactions. The secretion protein $(\sec \mathrm{A})$ gene was also amplified with the primer pair SecAfor1/SecArev3. The direct PCR product was diluted 30 -fold and used as a DNA template 
for PCR with primers SecAfor5/SecArev2 (Dickinson and Hodgetts, 2013). Total DNA extracts used as positive controls were coconut palms confirmed as CSPWD phytoplasma-infected from Ghana representing disease stages 1, 2 and 3 (provided by Dr. Ndede Yankey), and CILY phytoplasma-infected from Grand-Lahou villages: Badadon, Braffedon, Adjadon, Yaokro and Doudougbazou (Arocha Rosete et al., 2017). PCR cycling and annealing temperatures were as previously described (Arocha Rosete et al., 2017; Lorenz et al., 1995).

Five microliters of each of the PCR products were separated in a $1.5 \%$ agarose gel and visualized with SYBR Safe DNA Gel Stain (Invitrogen, USA) in an AlphaImager (Alpha Innotech, USA).

\subsection{Sequencing, restriction fragment length polymorphism (RFLP), and phylogenetic analyses}

Ten amplicons of each G813/AwkaSR, R16F2n/R2, U5/U3 and secA PCR product per village (except Amanikro) were purified on spin columns (E.Z.N.A Cycle Pure, Omega Bio-tek, USA), cloned according to manufacturer's instructions (Easy Vector Systems, Promega, USA) and sequenced bi-directionally using M13F/M13R primers (Centre for the Analysis of Genome Evolution and Function, CAGEF, University of Toronto). The consensus 16S rDNA and secA sequences were deposited in GenBank and compared by BLAST (Altschul et al., 1990) with available phytoplasma sequences. Sequences obtained were aligned and phylogenetic trees were constructed using the neighbour-joining method with MEGA version 6.0. (Kumar et al., 2016) with default values and 1000 replicates for bootstrap analysis.

The R16F2n/R2 sequences were analysed with iPhyClassifier (Zhao et al., 2009) for preliminary identification of the phytoplasmas detected in the insect samples based on in silico restriction profiles. G813/AwkaSR, secA and U5/U3 sequences were assessed with in silico restriction endonucleases using the virtual gel plotting program pDRAW32 (http://www.acaclone.com) to identify the enzymes yielding polymorphisms that could distinguish among the phytoplasma strains. Ten microliters of the G813/AwkaSR, secA and U5/U3 PCR amplicons were digested with RsaI, HaeIII, AluI, MboII, and TaqI restriction endonucleases (New England Biolabs, Canada), following manufacturer's recommendations. RFLP profiles were visualized in a $3 \%$ agarose or $6.7 \%$ polyacrylamide gel stained with $\mathrm{SYBR}^{\mathrm{R}}$ Safe DNA Gel Stain (Invitrogen, USA) in a gel documenter (Alpha Innotech, USA).

\section{Results}

Surveys were conducted in the villages of Adjadon, Amanikro, Badadon, Braffedon, Doudougbazou and Yaokro, located at the south littoral of Grand-Lahou. Results revealed the presence of eight major Hemiptera families: Aphrophoridae, Achilidae, Derbidae, Flatidae, Membracidae, Pentatomidae, Tropiduchidae, and Cicadellidae (Table 1). Specimens from the families Cicadellidae and Derbidae were the most widespread. Specimens of Derbidae included Kamendaka albomaculata (Muir), Phenice stellulata (Boheman), Diostrombus dilatatus (Westwood), and Proutista fritillaris (Boheman). The family Cicadellidae was represented by a recently described genus and species of the tribe Erythroneurini, Nedotepa curta Dmitriev (Cicadellidae: Typhlocybinae: Erythroneurini) (Dmitriev, 2016).

Specimens of $N$. curta were the only species of leafhopper collected on coconut palms from all villages: Adjadon (26), Amanikro (4), Badadon (103), Braffedon (99), Doudougbazou (22) and Yaokro (42). This leafhopper was the most abundant hemipteran insect on coconut palm overall. Derbidae was the second most collected family in the villages of Braffedon (12, K. albomaculata, $P$. stellulata, D. dilatatus); Badadon (6, K. albomaculata, P. stellulata, D. dilatatus), and Yaokro (2, $P$. fritillaris). Flatidae was the third most common in Doudougbazou (14) and Adjadon (12) followed by Membracidae (16) limited to Amanikro. Achilidae (3), Aphrophoridae (3, Aphrophora sp.) and Tropiduchidae (1, Tangia sp.) were the least represented families restricted to Amanikro, Braffedon and Badadon, respectively. Badadon was the only village where two Derbidae specimens ( $D$. dilatatus) were found in weeds, one in $D$. saxatilis and one in $B$. nitida.

Dmitriev (2016) provided a morphological description and detailed illustrations of Nedotepa curta based on specimens collected from coconut palm in the Western Region of Ghana. The specimens collected in the present study represent the first records of this species from Côte d'Ivoire. Specimens from Côte d'Ivoire appear to be morphologically identical to specimens of the type series from Ghana (cf. Fig. 1 to illustrations in Dmitriev (2016).

This species may be recognized by the following combination of morphological features: length including wings $3.5-4.0 \mathrm{~mm}$; body slender, elongate; color bright yellow with lateral margins of head and scutellum white and apex of scutellum dark brown; head slightly narrower than pronotum, ocelli absent, crown convex with anterior and posterior margins parallel in dorsal view, coronal suture absent; pronotum and mesonotum strongly convex in lateral view; forewing with inner apical cell oblique basally; male abdominal apodemes vestigial; pygofer with prominent dorsal membranous lobe near base, dorsal margin angulately emarginate, apex acutely angled and darkly sclerotized; subgenital plate triangular with setae strongly reduced in size; style linear with preapical lobe narrow; connective U-shaped, without stem or median anterior lobe; aedeagus slender, curved dorsad, with small posterior spine near midlength and pair of long apical processes extended ventrolaterad; female ovipositor very short with blades vestigial.

This species resembles some other tropical African members of the tribe Erythroneurini in body proportions, coloration, and wing venation. In the form of the male genitalia, Nedotepa is perhaps most similar to the widespread African genera Molopopterus Jacobi and Nsimbala Dworakowska, but may be separated from the former by the lack of ocelli and lack of a median anterior lobe on the male connective, and

Table 1

Hemiptera families collected and tested by PCR specific for the CILY phytoplasma (G813/AwkaSR primers) in six villages of Grand-Lahou. NC: not collected.

\begin{tabular}{|c|c|c|c|c|c|c|c|}
\hline \multirow[t]{3}{*}{ Family } & \multicolumn{7}{|c|}{ No. specimens nPCR positive/No. specimens collected } \\
\hline & \multicolumn{7}{|l|}{ Village } \\
\hline & Adjadon & Amanikro & Badadon & Braffedon & Doudougbazou & Yaokro & Total \\
\hline Cicadellidae (N. curta) & $17 / 26$ & $0 / 4$ & $91 / 103$ & $69 / 99$ & $15 / 22$ & $24 / 42$ & $216 / 296$ \\
\hline Derbidae & NC & NC & $0 / 6$ & $0 / 12$ & $\mathrm{NC}$ & $2 / 2$ & $2 / 20$ \\
\hline Tropiduchidae & NC & NC & $0 / 1$ & NC & $\mathrm{NC}$ & NC & $0 / 1$ \\
\hline Membracidae & NC & $0 / 16$ & NC & $\mathrm{NC}$ & $\mathrm{NC}$ & NC & $0 / 16$ \\
\hline Pentatomidae & NC & NC & $\mathrm{NC}$ & $0 / 4$ & $0 / 2$ & $\mathrm{NC}$ & $0 / 6$ \\
\hline Flatidae & 0/12 & NC & NC & $\mathrm{NC}$ & $0 / 14$ & NC & $0 / 26$ \\
\hline Aphrophoridae & NC & $\mathrm{NC}$ & $\mathrm{NC}$ & $0 / 3$ & $\mathrm{NC}$ & NC & $0 / 3$ \\
\hline Achilidae & NC & $0 / 3$ & $\mathrm{NC}$ & $\mathrm{NC}$ & $\mathrm{NC}$ & $\mathrm{NC}$ & $0 / 3$ \\
\hline Total & $17 / 38$ & $0 / 23$ & $91 / 110$ & $69 / 118$ & $15 / 38$ & $26 / 44$ & $218 / 361$ \\
\hline
\end{tabular}




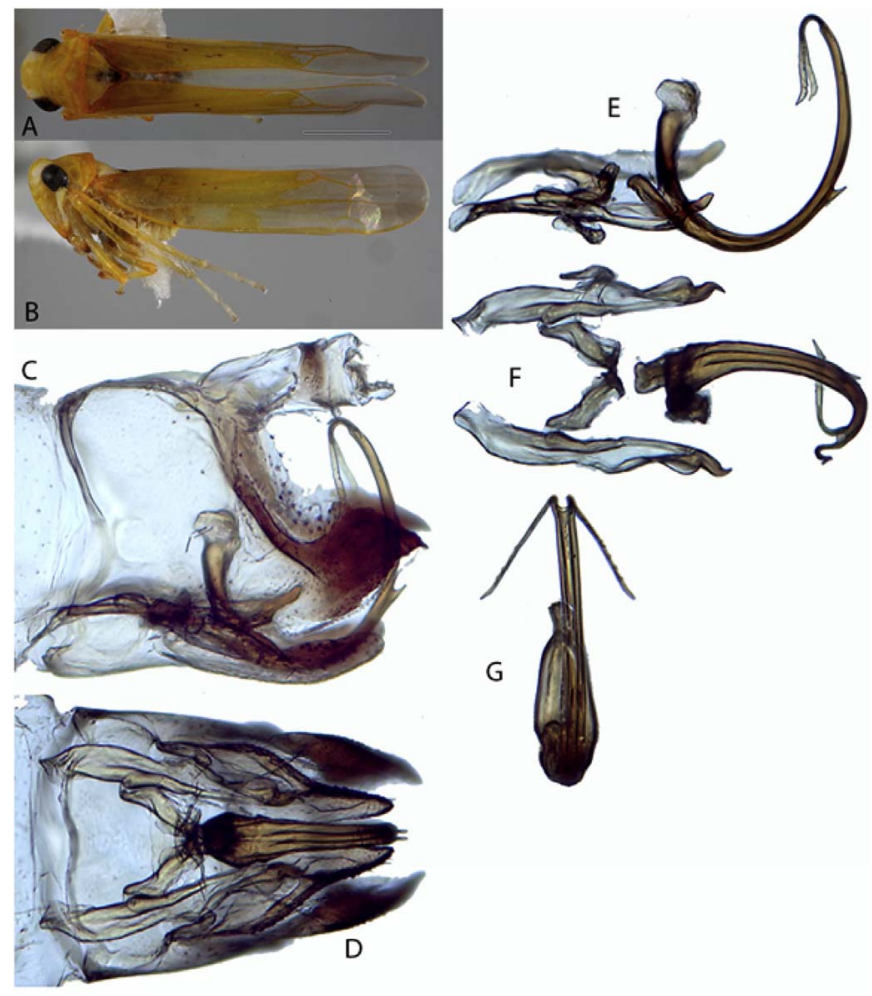

Fig. 1. Nedotepa curta Dmitriev: A-B, adult female, dorsal and lateral habitus (scale $=1 \mathrm{~mm}$ ); C-D, male genital capsule, lateral and ventral views; E-F, male genitalia (aedeagus, styles and connective), lateral and ventral views; G, aedeagus, posterior view.

from the latter by the lack of a coronal suture.

The strongly reduced ovipositor of the coconut palm feeding species is unique and presumably related to the unusual oviposition behavior of the females, which lay eggs on the surface of the leaves instead of inserting them into plant tissue. All other species of Erythroneurini for which females have been studied have the ovipositor well developed and similar to those of other Typhlocybinae.

A total of two hundred and ninety six specimens of $N$. curta were collected and two hundred sixteen (216/296) were positive for the CILY phytoplasma (73\%) by PCR with P1/P7 followed by G813/AwkaSR (Table 1) and U5/U3 primers. For the secA PCR, 191/296 (64.5\%) specimens yielded amplicons. G813/AwkaSR sequences representative of $N$. curta specimens of each village were deposited in GenBank (Figs. 3 and 6). Only two specimens of $P$. fritillaris (Derbidae) were part of the coconut plantation entomofauna. These specimens were collected in Yaokro, and both tested positive for the CILY phytoplasma (16SrXXIIB). Their G813/AwkaSR sequences were deposited in GenBank (Ac. ns. KY111734, KY111735). No amplicons were obtained from the phytoplasma-free $N$. curta specimens collected in Ghana.

G813/AwkaSR RsaI RFLP profiles (Fig. 2) for the CILY phytoplasma strains (subgroup 16SrXXII-B) identified from coconut palms and $N$. curta, were identical to those from the CSPWD from Ghana and cluster with phytoplasmas in subgroup 16SrXXII-B 'Ca. P. palmicola' - related strains (Fig. 3). For the CILY phytoplasma strains identified from the coconut palms and the $N$. curta as members of the subgroup 16SrXXII-B 'Ca. P. palmicola' - related strains, both TaqI and MboII SecA RFLP profiles were identical to those shown by CSPWD from Ghana (Fig. 4, Lanes 4, 5, 6, 7, 8, 10 and 12). This was also supported by the clustering of those strains with phytoplasmas classified as 16SrXXII-B (Fig. 5). No G813/AwkaSR or secA amplicons were obtained for any of the other Hemiptera specimens captured from CILY-affected coconut palms in Grand-Lahou. On the other hand, TaqI and MboII secA RFLP profiles for the CILY phytoplasma strains of group 16SrI identified from coconut palms and N. curta in Badadon and Yaokro (Fig. 4, Lanes 1, 2, 3, 9 and

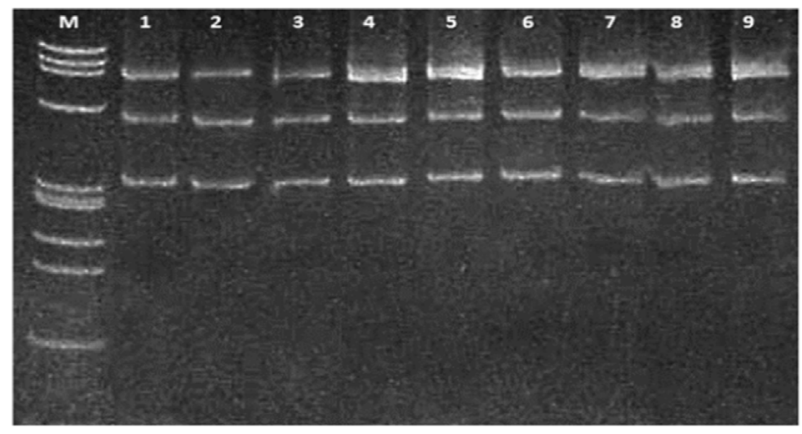

Fig. 2. RsaI RFLP patterns in polyacrylamide $6.7 \%$ gels of G813/AwkaSR amplicons from $N$. curta and coconut palms from Côte d'Ivoire and Ghana. Lanes 1, 2, 3, 4, 5: N. curta (Badadon, Braffedon, Adjadon, Yaokro, Doudougbazou); Lane 6: Ghana CSPWD phytoplasma (disease stage 2); Lanes 7, 8, 9: CILY phytoplasma (palms from Badadon, Braffedon, Adjadon). M: marker phiX174 HaeIII digested with fragment sizes in base pairs from top to bottom of $1353 ; 1078 ; 872 ; 603 ; 310 ; 281 ; 271 ; 234 ; 194 ; 118$, and 72 .

11) were similar to the profiles shown by reference phytoplasmas of group 16SrI. The phylogenetic tree based on the secA sequences shows how these CILY phytoplasma strains cluster with members of the group 16SrI (Fig. 5).

Out of a total of 54 symptomatic palms sampled, 52 yielded G813/ AwkaSR amplicons confirming the presence of the CILY phytoplasma. However, the U5/U3 and secA sequences of the phytoplasmas identified from four of the symptomatic coconut palms and two $N$. curta specimens (one from Badadon and one from Yaokro) were 99\% similar to sequences from group $16 \mathrm{SrI}$, 'Ca. P. asteris'-related strains. The symptomatic coconut palms were from Badadon (one palm exhibiting symptoms of disease stage 3 and yielding G813/AwkaSR amplicons, and two palms showing symptoms of disease stage 2 , and negative with G813/AwkaSR PCR); and one coconut palm from Yaokro, showing symptoms of disease stage 3 with positive PCR for G813/AwkaSR. Interestingly, samples of $D$. saxatilis and $B$. nitida plants collected in Badadon yielded U5/U3 amplicons whose sequences were also 99\% similar to those of the group $16 \mathrm{SrI}$ ' $\mathrm{Ca}$. P. asteris'. The U5/U3 consensus sequences corresponding to $16 \mathrm{SrI}$ phytoplasma strains were deposited in GenBank (Ac. nos KY111738_Badadon; KY111739_Yaokro from coconut palms); (Ac. nos KY111736_Badadon; KY111737_Yaokro from $N$. curta), and (Ac. nos. KY111741 and KY111740, from D. saxatilis and B. nitida, respectively). The secA consensus sequences corresponding to 16SrI phytoplasma strains were deposited in GenBank (Ac. nos. KY244147_Yaokro; KY244148_Badadon from coconut palms), (Ac. ns. KY111756_Badadon; KY111755_Yaokro from $N$. curta), and (Ac. ns. KY111757and KY111758, from D. saxatilis and B. nitida, respectively). RFLP profiles of the secA sequences of the 16SrI phytoplasma strains detected in Badadon and Yaokro were identical to those of the 16SrI controls (Fig. 4). The clustering of these phytoplasmas within phytoplasmas classified in 16SrI group was confirmed through phylogenetic analyses based on both secA (Fig. 5) and 16S rRNA (Fig. 6) gene sequences.

\section{Discussion}

Nedotepa curta, has been identified as a potential vector for the CILY phytoplasma in Côte d'Ivoire based on results obtained in this study. $N$. curta was the most abundant hemipteran collected from coconutgrowing areas in Grand-Lahou, which tested positive for the presence of CILY phytoplasma. Both the 16S rDNA and secA sequences of CILY phytoplasma from $N$. curta specimens were $99 \%$ identical to those of the CILY phytoplasma previously identified (Arocha Rosete et al., 2017) from the villages of Badadon, Braffedon, Adjadon, Doudougbazou, and Yaokro. Moreover, the CILY phytoplasma was detected in 216/296 (73\%) of the N. curta specimens captured from CILY-affected and CILY phytoplasma-infected coconut palms from all the villages surveyed. 


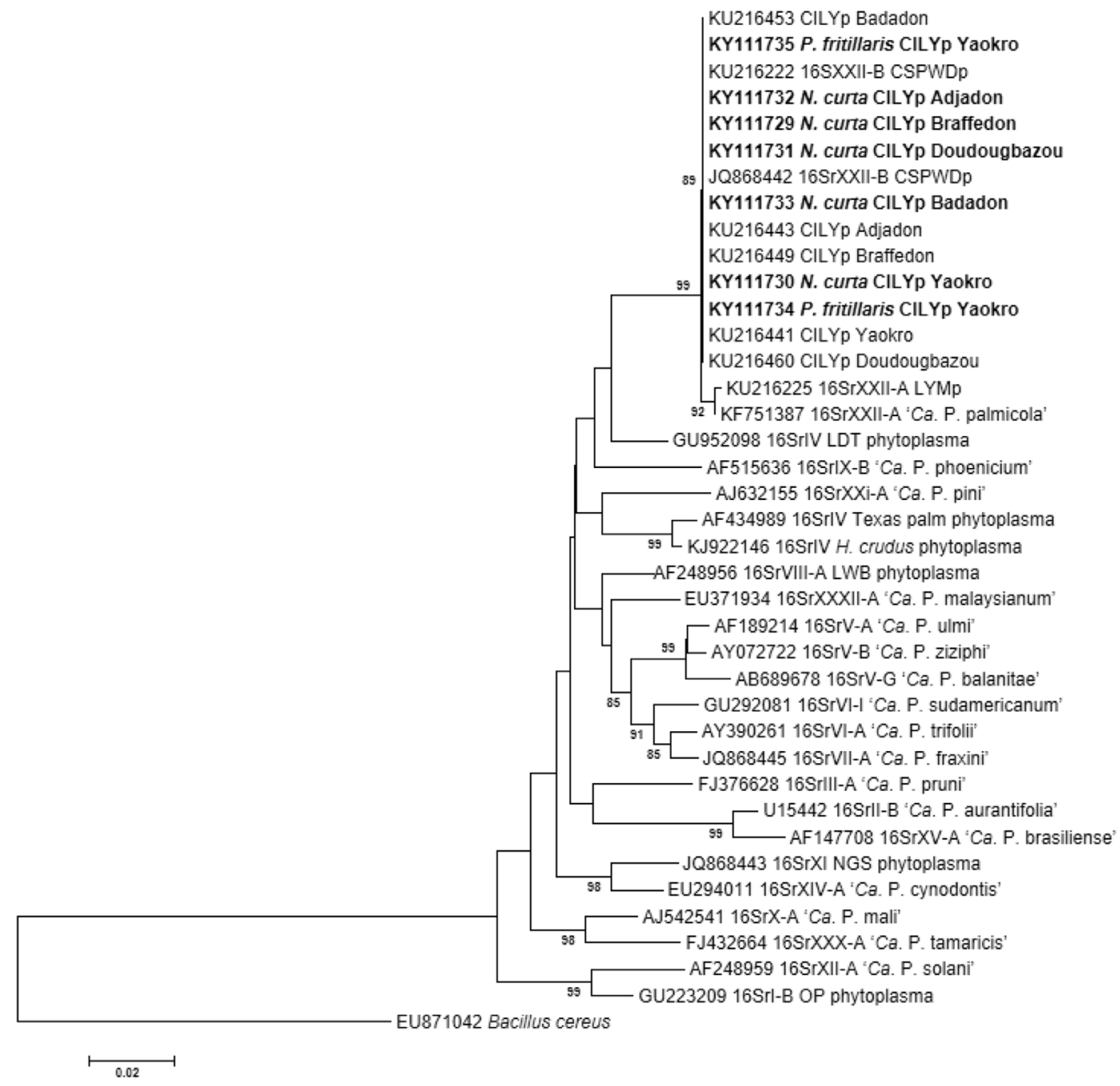

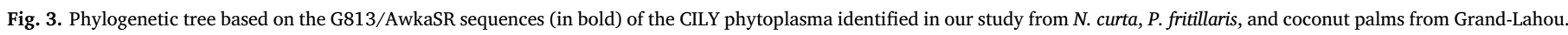

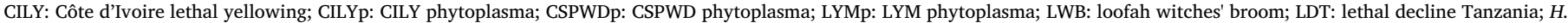

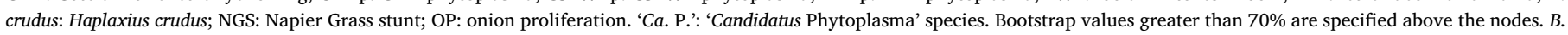
cereus was used as outgroup to root the tree.

Also, the percentages of detection for the CILY phytoplasma from $N$. curta specimens were the highest for Badadon (the westernmost village) and Braffedon (the easternmost village) (Table 1). Previous studies reported Badadon and Braffedon as the most severely CILY-affected villages and those with the highest percentages of CILY phytoplasma detection (Arocha Rosete et al., 2017).

Although these results strongly suggest $N$. curta as potential vector of the CILY phytoplasma, the phytoplasma vectoring capacity of this species still needs to be proven through transmission tests. $N$. curta was first observed in Ghana (Dmitriev, 2016), but a previous attempt to confirm it as a vector for the CSPWD phytoplasma, which is closely related to the CILY phytoplasma, failed (Philippe et al., 2009). During this study, leafhopper specimens collected from Adjadon, Amanikro Badadon, Braffedon, Doudougbazou and Yaokro were confirmed, through morphological comparison, as the same species as the palm leafhopper (Fig. 1) previously reported and only recently named (Dmitriev, 2016) from Ghana, and were widespread among the CILYaffected coconut farms of Grand-Lahou.

$N$. curta belongs to the highly diverse and globally distributed leafhopper subfamily Typhlocybinae (microleafhoppers). Very few species of Typhlocybinae have previously been shown to be competent vectors of phytoplasma diseases (Galetto et al., 2011). The ability of typhlocybines to transmit phloem-borne pathogens such as phytoplasmas is thought to be limited, in part, by the apparent preference of most studied species for feeding on leaf parenchyma cell contents (mesophyll) rather than vascular fluids, but some species have been shown to feed, at least occasionally, on xylem and phloem sap (Saguez et al., 2015). Because phytoplasmas are phloem-limited in plants, the high rates of PCR detection of CILY phytoplasma in specimens of $N$. curta strongly suggests that this leafhopper species ingests phloem sap.

To date, the most documented phytoplasma vectors belonging to the Typhlocybinae are members of the tribe Empoascini (Galetto et al., 2011) enclosing Empoasca papayae, proven as vector of the phytoplasma associated with Bunchy Top Symptom of papaya (Acosta Perez et al., 2010). Other reports of typhlocybine vectors of phytoplasmas include $E$. decedens as a vector of European stone fruit yellows in Italy (Pastore et al., 2004) and potential vector in Lebanon for almond witches' broom (Abou-Jawdah et al., 2014); E. decipiens in Saudi Arabia for the lime decline disease (Alhudaib et al., 2009), alfalfa witches' broom (Al-Saleh et al., 2014), ranunculus virescence in Italy (Parrella et al., 2005) and almond witches' broom in Lebanon (Dakhil et al., 2011); and E. kraemeri for phytoplasmas infecting citrus species (C. sinensis and $C$. limon), coffee (Coffea arabica), periwinkle (Catharanthus roseus), and tabebuia (Tabebuia heterophylla) in Puerto Rico (Caicedo et al., 2015). Empoasca fabae and Erythroneura ziczac Walsh have been found as 
$\begin{array}{llllllllllll}M & 13 & 14 & 15 & 16 & 17 & 18 & 19 & 20 & 21 & 22 & 23\end{array}$

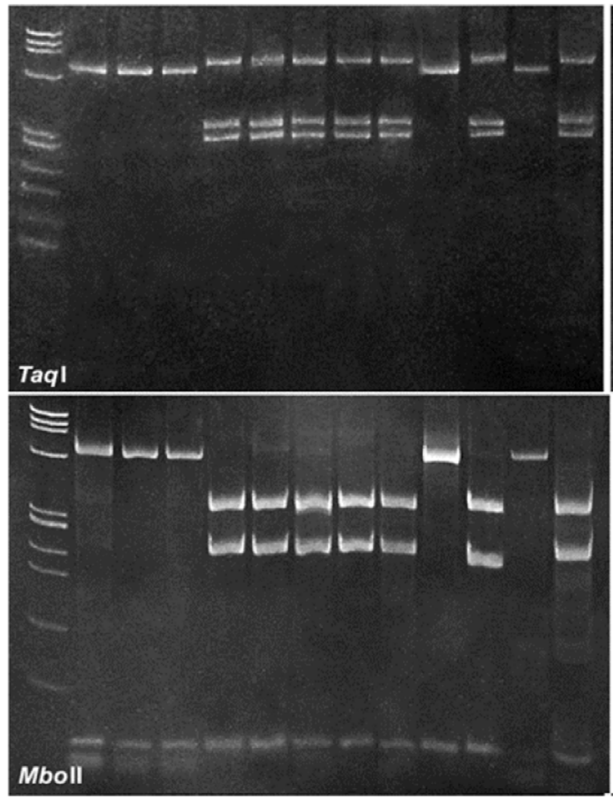

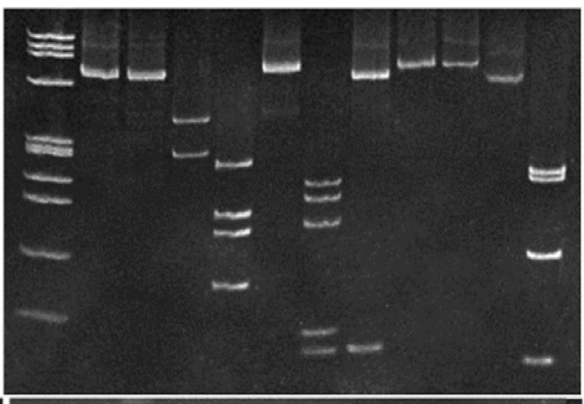

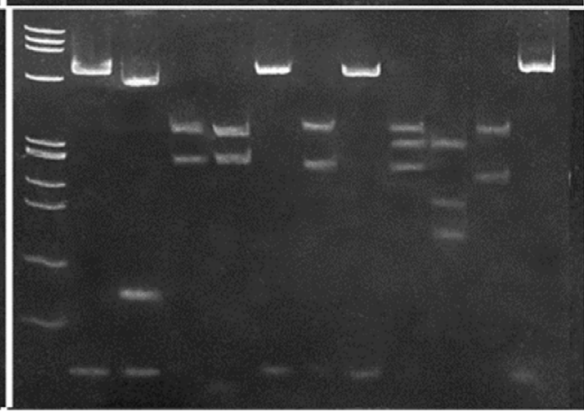

Fig. 4. TaqI and MboII RFLP patterns in polyacrylamide $6.7 \%$ gels of secA amplicons of phytoplasmas detected in $N$. curta, coconut palms and weeds $D$. saxatilis and $B$. nitida. Lanes 1: palm from Yaokro (16SrI); Lanes 2, 3: $N$. curta from Badadon and Yaokro (16SrI); Lanes 4, 5, 6: palms from Badadon, Braffedon and Yaokro (16SrXXII-B); Lanes 7, 8: $N$. curta from Badadon and Braffedon (16SrXXII-B); Lane 9: $D$. saxatilis from Badadon (16SrI); Lane 10: N. curta fromYaokro (16SrXXII-B); Lane 11: B. nitida from Badadon (16SrI); Lane 12: Ghana CSPWD phytoplasma, 16SrXXII-B (palms with disease stage 2); Lane 13: PRIVA, primula virescence aster yellows (16SrI-B); Lane 14: A-AY, apricot aster yellows (16SrI-F); Lane 15: FBP, faba bean phyllody (16SrII-C); Lane 16: CX, X-disease of peach (16SrIII-A - 'Ca. P. pruni'); Lane 17: ULW, elm witches' broom (16SrV-A 'Ca. P. ulmi'); Lane 18: CP1, clover proliferation (16SrVI-A - 'Ca. P. trifolii'); Lane 19: ASHY, ash yellows (16SrVII-A 'Ca. P. fraxini'); Lane 20: ESFY, European stone fruit yellows (16SrX-B - 'Ca. P. prunorum'); Lane 21: PD, pear decline (16SrX-C - 'Ca. P. pyri'); Lane 22: AP, apple proliferation (16SrX-A - 'Ca. P. mali'); Lane 23: MOL, "Molière" disease (16SrXII-A - 'Ca. P. solani'); M: marker phiX174 HaeIII digested with fragment sizes in base pairs from top to bottom of $1353 ; 1078 ; 872 ; 603 ; 310 ; 281 ; 271$; $234 ; 194 ; 118$, and 72 . carriers of 'Ca. P. asteris' in Canada (Olivier et al., 2014). Only a single species of the Typhlocybinae tribe Erythroneurini (which includes. $N$. curta) has, so far, been shown to be capable of infecting plants with a phytoplasma in the laboratory - Tautoneura mori (Matsumura) - for the mulberry dwarf phytoplasma (Jiang et al., 2005).

Diostrombus and Proutista are reported to be common derbids in West Africa (Wilson 1987) and species of these genera have been reported as the potential vectors of LD in Tanzania (Mpunami et al., 2000), LY in Mozambique (Bila, 2016), and Kerala Wilt disease in India (Edwin and Mohankumar, 2007), although their transmission capacity has not been yet proven. In this study 20 derbid specimens were collected from three villages and, among these, only two specimens of $P$. fritillaris was limited to Yaokro village, where both yielded PCR positive results for the CILY phytoplasma. P. fritillaris was very poorly

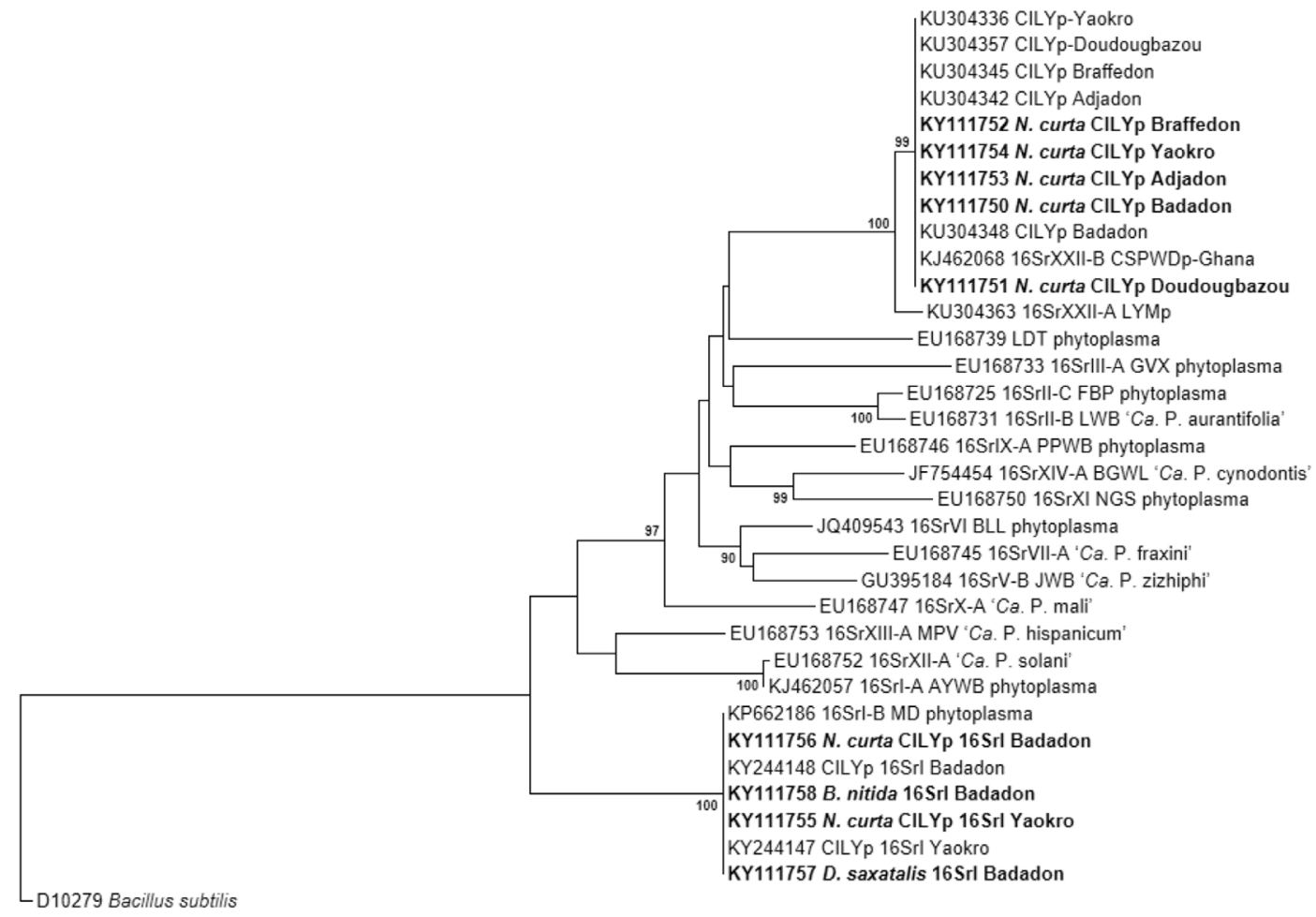

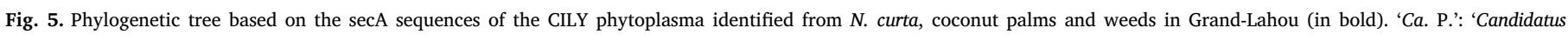

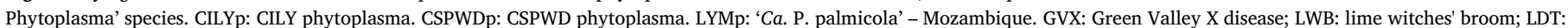

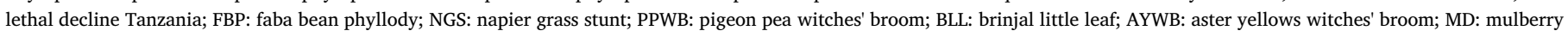
dwarf. Bootstrap values greater than $70 \%$ are specified above the nodes. B. subtilis was used as outgroup to root the tree. 


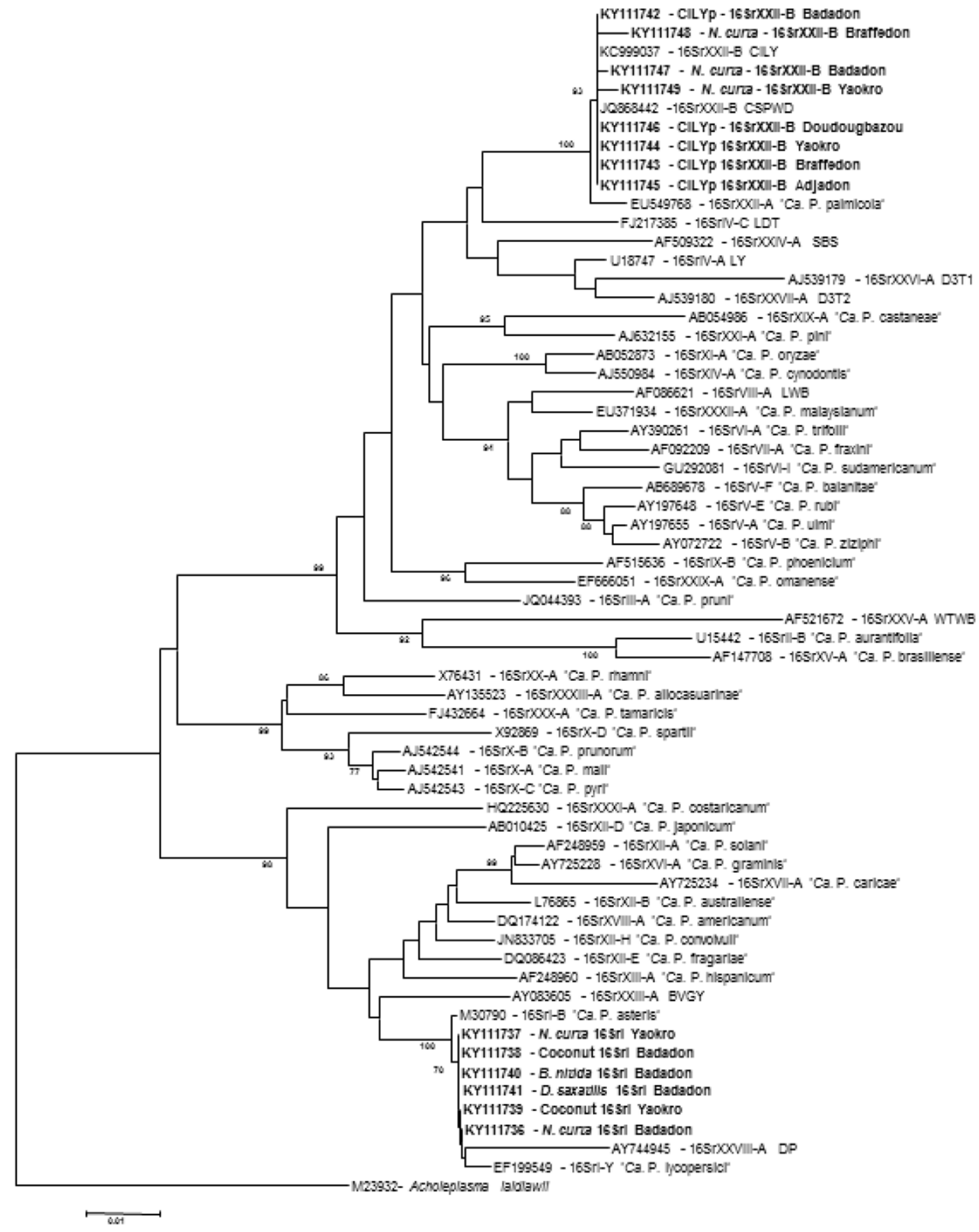

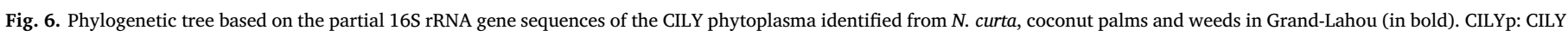

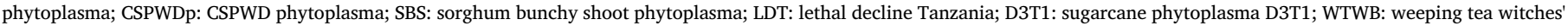

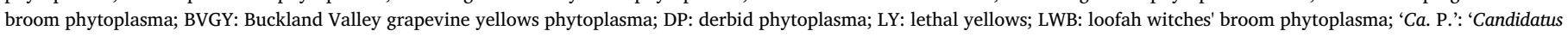
Phytoplasma' species. Acholeplasma laidlawii was used as outgroup. Bootstrap values greater than $70 \%$ are specified above the nodes.

represented among the hemipteran fauna from coconut palms in the region; they may be occasional carriers of the CILY phytoplasma in the coconut farm of Yaokro, and it seems unlikely that they play a major role in the spread of CILY. Nevertheless, a larger sampling is in progress to further determine whether more $P$. fritillaris specimens may be present in other coconut-growing villages to verify whether they can also be carriers of the CILY phytoplasma. On the other hand, it is interesting that $D$. dilatatus specimens were also found in weeds $D$. saxatilis and $B$. nitida collected from Badadon village, which were previously identified within the weed flora of coconut palms limited to that village with PCR results negative for the CILY phytoplasma (Arocha Rosete et al., 2016). D. saxatilis and B. nitida also yielded PCR negative results for the CILY phytoplasma in the present study, but were confirmed as secondary hosts for the 16 SrI phytoplasma, although their epidemiological role is not yet clear.

No data on the fluctuations of $N$. curta populations throughout the rainy or dry seasons are available from Ghana nor from Côte d'Ivoire. In Côte d'Ivoire, the dry seasons range from December to April, and from August to September; while the rainy seasons range from May to July, and from October to November (Arocha Rosete et al., 2017). Although in this study, hemipteran were collected during both dry and rainy seasons, observations suggest that $N$. curta populations were dominating during the rainy season (K.E. Kwadjo, unpublished), particularly in May and September 2015 where the highest number of 
specimens were captured, and confirmed as phytoplasma carriers, followed by the month of April 2016, which falls within the dry season. It is noteworthy that the SODEXAM (Société d'Exploitation et de Devéloppement aéroportuaire, Aéronautique et Météorologique) in Côte d'Ivoire (H. A. Diallo, unpublished), registered a severe drought during 2015 and early 2016 , where January $(1.2 \mathrm{~mm})$ and September $(7.7 \mathrm{~mm})$ received the lowest amount of rainfall, and April was the hottest month (mean $27.45^{\circ} \mathrm{C}$ ). However, it is not clear whether such climate factors may be associated with $N$. curta populations' occurrence during those particular sampling months.

The fact that the 16S rDNA sequences of the 16SrI phytoplasma detected in two specimens of $N$. curta from Badadon were $99 \%$ identical to those four CILY-affected coconut palms in Badadon and Yaokro, suggests that $N$. curta may be able to transmit both 16 SrXXII-B and 16SrI phytoplasmas across the CILY-affected coconut farms. However, the role of the 16SrI phytoplasma in the development and spread of CILY is not clear. Four out of 54 symptomatic coconut palms (7.4\%) were infected with the 16SrI phytoplasma, among which, two of them, one from Badadon, and one from Yaokro, both exhibiting symptoms of disease stage 3 , were co-infected with the 16 SrXXII-B phytoplasma. This indicates that mixed phytoplasma infection of the 16SrXXII-B and 16SrI phytoplasmas may occurs in coconut groves in Grand-Lahou, although it seems to occur at a low rate since only two coconut palms (3.7\%) harbored both 16SrI and 16SrXXII-B phytoplasmas. Moreover, it is noteworthy that the $16 \mathrm{SrXXII-B}$ phytoplasma was not detected in two of the symptomatic coconut palms from Badadon showing symptoms of disease stage 2 , where only the 16 SrI phytoplasma was identified.

Mixed phytoplasma infections naturally occur in coconut and other palm species. Bila et al. (2015) identified LY-affected coconut palms in Mozambique co-infected with 'Ca. P. palmicola'- and 'Ca. P. pini'-related strains. In Malaysia, the popular evergreen foxtail palm Wodyetia bifurcata was reported as a host for two different phytoplasmas, 16SrXIV, ('Ca. P. cynodontis') group and 'Ca. P. asteris' (Naderali et al., 2013). A 16SrI phytoplasma was associated with the Al-Wijam disease of date palm (Phoenix dactylifera) in Saudi Arabia (Alhudaib et al., 2007), and the lethal wilt of oil palm (Elaeis guineensis Jacq.) in Colombia (Alvarez et al., 2014). The $16 \mathrm{SrXI}$ (' $\mathrm{Ca}$. P. oryzae') group (Manimekalai et al., 2010) and 'Ca. P. asteris' (Naderali et al., 2013) have been associated with diseases of arecanut (Areca catechu L.) in India. Therefore, the fact that the group 16SrI phytoplasma was detected from $N$. curta specimens captured from coconut farms affected by CILY in Grand-Lahou is highly significant since this is the phtoplasma group with the widest plant host range and most complex epidemiology (Lee et al., 2003).

Epidemiological conditions in Badadon and Yaokro associated with the presence and spread of the $16 \mathrm{SrI}$ phytoplasma by the $N$. curta as well as the possible effect of disease stage 3 on the occurrence of 16SrI and 16 SrXXII-B phytoplasma mixed infections, or disease stage 2 on the sole detection of the $16 \mathrm{SrI}$ phytoplasma are not clear, and require further investigation. On the other hand, since $D$. saxatilis and $B$. nitida harbor a 16SrI phytoplasma strain, which has been also found in a few other coconut palms in Badadon and Yaokro, it is very likely that these two new alternative plant hosts of the 16SrI phytoplasma may also hasten the spread of CILY disease or worsen its severity. A larger sampling of coconut palms and hemipteran, and further characterization studies would help elucidate the epidemiological factors related to the occurrence of phytoplasma group 16SrI, or its presence in mixed infection with the 16SrXXII-B phytoplasma in coconut palms of GrandLahou and in $N$. curta populations. The sampling would also help understanding their role in CILY development and spread in Grand-Lahou.

Although PCR detection of the phytoplasma in an insect does not prove the insect's vector capacity unless transmission trials are performed (Bosco and D'Amelio, 2010), the results strongly support the possible role of $N$. curta as vector for the CILY phytoplasma. Transmission cage trials are currently ongoing with $N$. curta populations in pilot farms of Grand-Lahou under different disease pressure levels to prove $N$. curta's vector capacity and study its biology and epidemiology.

\section{Conclusions}

Although further study is needed to prove the role of $N$. curta as vector of the CILY phytoplasma, this work provides strong evidences that indicate $N$. curta as a potential vector involved in the spread of CILY throughout CILY-affected coconut farms in Grand-Lahou. Moreover, CILY phytoplasma-infected coconut palms may be co-infected with $16 \mathrm{SrI}$ phytoplasma strains suggesting that management and control of the coconut lethal yellowing disease in Grand-Lahou may be cumbersomed by a complex epidemiology.

\section{Funding}

This work was supported by the International Development Research Centre (IDRC), Ottawa, Canada, www.idrc.ca, [Grant No. 107789], with financial support from the Government of Canada, provided through Foreign Affairs, Trade and Development Canada (DFATD), www.international.gc.ca.

\section{References}

Abou-Jawdah, Y., Sater, A., Jawhari, M., Alma, A., 2014. Asymmetrasca decedens (Cicadellidae, typhlocybinae), a natural vector of 'candidatus phytoplasma phoenicium'. Ann. Appl. Biol. 165, 395-403.

Acosta Perez, K., Piñol, B., Arocha Rosete, Y., Wilson, M., Boa, E., Lucas, J., 2010. Transmission of the phytoplasma associated with bunchy top symptom of papaya by Empoasca papayae Oman. J. Phytopathol. 158, 194-196.

Alhudaib, K., Arocha Rosete, Y., Wilson, M., Jones, P., 2007. First report of a 16SrI, 'Candidatus Phytoplasma asteris' group phytoplasma associated with a date palm disease in Saudi Arabia. New Disease Reports 15, 12.

Alhudaib, K., Arocha Rosete, Y., Wilson, M., Jones, P., 2009. Molecular identification, potential vectors and alternative hosts of the phytoplasma associated with a lime decline disease in Saudi Arabia. Crop Protect. 28, 13-18.

Al-Saleh, M.A., Amer, M.A., Al-Shahwan, I.M., Abdalla, O.A., Damiri, B.V., 2014. Detection and molecular characterization of alfalfa witches' broom phytoplasma and its leafhopper vector in Riyadh Region of Saudi Arabia. Int. J. Agric. Biol. 16, 300-306.

Altschul, S., Gish, W., Miller, W., Meyers, E., Lipman, D., 1990. Basic local alignment search tool. J. Mol. Biol. 215, 403-410.

Alvarez, E., Mejía, J.F., Contaldo, N., Paltrinieri, S., Duduk, B., Bertaccini, A., 2014 'Candidatus Phytoplasma asteris' strains associated with oil palm lethal wilt in Colombia. Plant Dis. 98, 311-318.

Arocha-Rosete, Y., Konan Konan, J.L., Atta Diallo, H., Allou, K., Scott, J.A., 2014. Identification and molecular characterization of the phytoplasma associated with a lethal yellowing-type disease of coconut in Côte d'Ivoire. Can. J. Plant Pathol. 36, $141-150$.

Arocha Rosete, Y., Atta Diallo, H., Konan Konan, J.L., Kouamé, A.E.P., Séka, K., Kra, K.D., Toualy, M.N., Kwadjo, K.E., Daramcoum, W.A.M.P., Beugré, N.I., Ouattara, B.W.M., Kouadjo Zaka, C.G., Allou, K., Fursy-Rodelec, N.D., Doudjo-Ouattara, O.N., Yankey, N., Dery, S., Maharaj, A., Saleh, M., Summerbell, R., Contaldo, N., Paltrinieri, S., Bertaccini, A., Scott, J., 2016. Detection and identification of the coconut lethal yellowing phytoplasma in weeds growing in coconut farms in Côte d'Ivoire. Can. J. Plant. Pathol. 38 (2), 164-173.

Arocha Rosete, Y., Atta Diallo, H., Konan Konan, J.L., Yankey, N., Saleh, M., Pilet, F., Contaldo, N., Paltrinieri, S., Bertaccini, A., Scott, J., 2017. Detection and differentiation of the coconut lethal yellowing phytoplasma in coconut-growing villages of Grand-Lahou, Côte d'Ivoire. Ann. Appl. Biol. http://dx.doi.org/10.1111/aab.12333.

Bila, J., Mondjana, A., Samils, B., Högberg, N., 2015. High diversity, expanding populations and purifying selection in phytoplasmas causing coconut lethal yellowing in Mozambique. Plant Pathol. 64, 597-604.

Bila, J., 2016. Coconut Lethal Yellowing Phytoplasma Disease in Mozambique Diversity, Host Range, and the Impact of Farming Practices on Disease Incidence. Doctoral Thesis. Swedish University of Agricultural Sciences, Uppsala, Sweden, pp. 70 ISSN 1652-6880.

Bosco, D., D'Amelio, R., 2010. Insect feeding behavior. Transmission, Specificity and Competition of multiple phytoplasmas in the insect vector. In: Weintraub, P., Jones, P. (Eds.), Phytoplasmas: Genome, Plant Hosts and Vectors. CAB International, pp. 293-309.

Brown, S.E., Been, B.O., McLaughlin, W.A., 2006. Detection and variability of the lethal yellowing group 16SrIV phytoplasmas in the Cedusa sp. (Hemiptera: auchenorrhynca: Derbidae) in Jamaica. Ann. Appl. Biol. 149, 53-62.

Caicedo, J.D., Rivera-Vargas, L.I., Segarra, A.E., Davis, R.E., 2015. Detection and molecular characterization of a group 16SrIX phytoplasma infecting citrus (Citrus sinensis and C. limon), coffee (Coffea arabica), periwinkle (Catharanthus roseus), and tabebuia (Tabebuia heterophylla) in Puerto Rico. Australas. Plant Dis. Notes 10, 28.

Ceotto, P., Bourgoin, T., 2008. Insights into the phylogenetic relationships within Cixiidae (Hemiptera: fulgoromorpha): cladistic analysis of a morphological dataset. Syst. 
Entomol. 33, 484-500.

Danyo, G., 2011. Review of scientific research into the Cape Saint Paul wilt disease (CSPWD) of coconut in Ghana. Afr. J. Agric. Res. 6, 4567-4578.

Dakhil, H.A., Hammad, E., El-Mohtar, C., Abou-Jawdah, Y., 2011. Survey of leafhopper species in almond orchards infected with almond witches' broom phytoplasma in Lebanon. J. Insect Sci. 11, 1-12.

Deng, S., Hiruki, C., 1991. Amplification of 16SrRNA genes from culturable and nonculturable molicutes. J. Microbiol. Meth. 14, 53-61.

Dickinson, M., Hodgetts, J., 2013. PCR analysis of phytoplasmas based on the secA gene. In: Dickinson, M., Hodgetts, J. (Eds.), Phytoplasmas: Methods and Protocols. Humana Press, Springer New York Heidelberg Dordrecht London, UK, pp. 205-217 ISSN 10643745.

Dietrich, H.C., 2013. Overview of the phylogeny, taxonomy and diversity of the leafhopper (Hemiptera: auchenorryncha: Cicadomorpha: membracoidea: Cicadellidae) vectors of plant pathogens. In: Proceedings of the 2013 International Symposium of Insect Vectors and Insect-borne Diseases, pp. 47-70.

Dmitriev, D.A., 2016. Three unusual species of Erythroneurini (Hemiptera: Cicadellidae) with descriptions of new genera. Zootaxa 4173, 183-191.

Dollet, M., Macome, F., Vaz, A., Fabre, S., 2011. Phytoplasmas identical to coconut lethal yellowing phytoplasmas from Zambesia (Mozambique) found in a pentatomide bug in Cabo Delgado province. Bull. Insectol. 64, S139-S140 (Supplement).

Edwin, B., Mohankumar, C., 2007. Molecular identification of Proutista moesta as the vector and the phylogenetic analysis of KWD in India. Indian J. Biotechnol. 6, $560-563$.

Foissac, X., Wilson, M.R., 2010. Current and possible future distributions of phytoplasma diseases and their vectors. In: Weintraub, P.G., Jones, P. (Eds.), Phytoplasmas: Genomes. Plant Hosts and Vectors.CABI, Wallingford, UK, pp. 309-324.

Galetto, L., Marzachi, C., DeMichelis, S., Bosco, D., 2011. Host plant determines the phytoplasma transmission competence of Empoasca decipiens (Hemiptera: Cicadellidae). J. Econ. Entomol. 104 (2), 360-366.

Gundersen, D.E., Lee, I.-M., 1996. Ultrasensitive detection of phytoplasmas by nested-PCR assays using two universal primer pairs. Phytopathol. Mediterr. 35, 144-151.

Halbert, S.E., Wilson, S.W., Bextine, B., Youngblood, S.B., 2014. Potential planthopper vectors of palm phytoplasmas in Florida with a description of a new species of the genus Omolicna (Hemiptera: fulgoroidea). Fla. Entomol. 97 (1), 90-97.

Harrison, N., Davis, R.E., Oropeza, C., Helmick, E., Narvaez, M., Eden-Green, S., Dollet, M., Dickinson, M., 2014. 'Candidatus Phytoplasma palmicola', a novel taxon associated with a lethal yellowing-type disease (LYD) of coconut (Cocos nucifera L.) in Mozambique. Int. J. Syst. Evol. Microbiol. 64, 1890-1899.

Harrison, N., Helmick, E., Elliot, M., 2008. Lethal yellowing-type diseases of palms associated with phytoplasmas newly identified in Florida, USA. Ann. Appl. Biol. 153, 85-94.

Harrison, N.A., Womack, M., Carpio, M.L., 2002. Detection and characterization of a lethal yellowing (16SrIV) group phytoplasma in Canary Island date palms affected by lethal decline in Texas. Plant Dis. 86, 676-681.

Howard, F.W., 2001. Sap feeders on palms. In: Howard, F.W., Moore, D., Giblin-Davis, R.M., Abad, R.G. (Eds.), Insects on Palms. CABI, New York, pp. 109-232.

Jiang, H., Saiki, T., Watanabe, K., Kawakita, H., Sato, M., 2005. Possible vector insect of mulberry dwarf phytoplasma, Tautoneura mori Matsumura. J. Gen. Plant Pathol. 71, 370-372.

Kumar, S., Stecher, G., Tamura, K., 2016. MEGA7: molecular evolutionary genetics analysis version 7.0 for bigger datasets. Mol. Biol. Evol. 33 (7), 1870-1874.

Lee, I.-M., Martini, M., Bottner, K.D., Dane, R.A., Black, M.C., Troxclair, N., 2003.
Ecological implications from a molecular analysis of phytoplasmas involved in an aster yellows epidemic in various crops in Texas. Phytopathology 93, 1368-1377.

Lorenz, K.H., Schneider, B., Ahrens, U., Seemüller, E., 1995. Detection of the apple proliferation and pear decline phytoplasmas by PCR amplification of ribosomal and nonribosomal DNA. Phytopathology 85, 771-776.

Lu, H., Wilson, B.A.L., Ash, G.J., Woruba, S.B., Fletcher, M.J., You, M., Yang, G., Gurr, G.M., 2016. Determining putative vectors of the Bogia Coconut Syndrome phytoplasma using loop-mediated isothermal amplification of single-insect feeding media. Sci. Rec. 6, 35801.

Manimekalai, R., Kumar, R.S., Soumya, V.P., Thomas, G.V., 2010. Molecular detection of phytoplasma associated with yellow leaf disease in areca palms (Areca catechu) in India. Plant Dis. 94 (11), 1376.

Mpunami, A., Tymon, A., Jones, P., Dickinson, M.J., 2000. Identification of potential vectors of the coconut lethal disease phytoplasma. Plant Pathol. 49, 355-361.

Naderali, N., Nejat, Vadamalai, G., 2013. First report of two distinct phytoplasma species, 'Candidatus Phytoplasma cynodontis' and 'Candidatus Phytoplasma asteris,' simultaneously associated with yellow decline of Wodyetia bifurcate (foxtail palm) in Malaysia. Plant Dis. 97, 1504.

Olivier, C., Saguez, J., Stobbs, L., Lowery, T., Galkaa, B., Whybournec, K., Bittner, L., Chene, X., Vincent, C. 2014. Occurrence of phytoplasmas in leafhoppers and cultivated grapevines in Canada. Agric. Ecosyst. Environ. 195, 91-97.

Pastore, M., Paltrinieri, S., Priore, R., Simeone, A.M., Raffone, E., Santonastaso, M., Bertaccini, A., 2004. Phytoplasma detection in Empoasca decedens Paoli and Empoasca spp. and their possible role as vectors of European stone fruit yellows (16SrX-B) phytoplasma. Acta Hortic. (Wagening.) 657, 507-511.

Parrella, G., Paltrinieri, S., Botti, S., Bertaccini, A., 2005. Molecular identification of phytoplasmas from virescent Ranunculus plants and from leafhoppers in Southern Italian crops. J. Plant Pathol. 90 (3), 521-527.

Philippe, R., Reignard, S., Descamps, S., Nkansak-Poku, J., Pilet, F., Fabre, S., Dollet, M., 2009. Study on the transmission of coconut lethal yellowing in Ghana. Ol. Crops Gras Lip. 16 (2), 102-106.

Saguez, J., Lemoyne, P., Giordanengo, P., Olivier, C., Lasnier, J., Mauffette, Y., Vincent, C., 2015. Characterization of the feeding behavior of three Erythroneura species on grapevine by histological and DC-electrical penetration graph techniques. Entomol. Exp. Appl. 157, 227-240.

Schneider, B., Seemüller, E., Smart, C.D., Kirkpatrick, B.C., 1995. Phylogenetic classification of plant pathogenetic mycoplasmalike organisms or phytoplasmas. In: In: Razin, S., Tully, J.G. (Eds.), Molecular and Diagnostic Procedures in Mycoplasmology, vol. I. Academic Press, San Diego, CA, USA, pp. 369-379.

Sullivan, M., Harrison, N., 2013. CPHST Pest Datasheet for 'Candidatus Phytoplasma Palmae' and Related Strains. USDA-APHIS-PPQ-CPHST. http://caps.ceris.purdue. edu.

Tymon, A.M., Jones, P., Harrison, N.A., 1998. Phylogenetic relationships of coconut phytoplasmas and the development of specific oligonucleotide PCR primers. Ann. Appl. Biol. 132, 437-452.

Weintraub, P.G., Beanland, L., 2006. Insect vectors of phytoplasmas. Annu. Rev. Entomol. 615 51, 91-111.

Wilson, M.R., 1987. African Derbidae (Homoptera: fulgoroidea): taxonomic notes with description of new species collected mainly from coconut. J. Nat. Hist. 21, 567-595.

Zhao, Y., Wei, W., Lee, I.-M., Shao, J., Suo, X., Davis, R.E., 2009. Construction of an interactive online phytoplasma classification tool, $i$ PhyClassifier, and its application in analysis of the peach X disease phytoplasma group (16SrIII). Int. J. Syst. Evol. Microbiol. 59, 2582-2593. 